\title{
E-LKPD Berbasis Technological Pedagogical Content Knowledge (TPACK): Sebuah Pengembangan Sumber Belajar Pembelajaran
} Fisika

\author{
Wilda Purnawati, Maison Maison, dan Haryanto Haryanto \\ Universitas Jambi \\ E-mail: wildapurnawati97@gmail.com
}

\begin{abstract}
Abstrak. Pengembangan E-LKPD berbasis Technological Pedagogical Content Knowledge (TPACK) dapat menjadi sebuah terobosan dalam meningkatkan kualitas pembelajaran. Tujuan penelitian ini adalah endeskripsikan proses pengembangan dan uji kelayakan E-LKPD berrbasis TPACK pada mata pelajaran Fisika. Penelitian ini merupakan penelitin dan pengembangan dengan mengembangakan media E-LKPD berbasis TPACK menggunakan model ADDIE (Analysis, Design, Develop, Implement, and Evaluate). Instrumen penelitian yang digunakan berupa angket validasi mediadan materi bersama ahli. Berdasarkan hasil pengembangan diketahui bahwa media pembelajaran E-LKPD yang dihasilkan dikategorikan sangat layak untuk digunakan dalam pembelajaran Fisika kelas X materi Suhu dan Kalor. Menurut penilaian para ahli media dan materi serta responden, masing-masing memberi skor untuk penilai dari ahli media diperoleh skor sebesar $96,42 \%$, sedangkan skor penilaian dari ahli materi sebesar 100\%. Kemudian dari respon guru diperoleh 88,39\% dan respon peserta didik 93\%. Skor tersebut termasuk dalam kategori sangat layak untuk digunakan. Pada penelitian ini proses pengembangan E-LKPD hanya memuat materi Suhu dan Kalor saja, sehingga selanjutnya dapat dikembangkan media pada materi lainnya.
\end{abstract}

Kata kunci: Penelitian Pengembangan, E-LKPD, TPACK, ADDIE.

\begin{abstract}
The development of E-LKPD based on Technological Pedagogical Content Knowledge (TPACK) can be a breakthrough in improving the quality of learning. The purpose of this study is to describe the process of development and feasibility testing of E-LKPD based on TPACK in Physics subjects. This research is research and development by developing TPACK-based E-LKPD media using the ADDIE model (Analysis, Design, Develop, Implement, and Evaluate). The research instrument used was a media material validation questionnaire with experts. Based on the results of the development, it is known that the resulting E-LKPD learning media is categorized as very feasible to be used in class X Physics learning material temperature and heat. According to the assessment of media and materials experts and respondents, each of them gave a score for the assessment of the media expert, a score of $96.42 \%$, and a score of material experts of $100 \%$. Then from the teacher response obtained $88.39 \%$ and $93 \%$ student response. This score is included in the group very can be done to use. In this research, the E-LKPD development process only contains temperature and heat material, so that further media can be developed on other materials.
\end{abstract}

Keywords: Development Reasearch, E-LKPD, TPACK, ADDIE 


\section{PENDAHULUAN}

Kehidupan di abad 21 mengharuskan manusia untuk selalu menggunakan teknologi dalam kehidupannya. Teknologi tidak hanya bermanfaat untuk berkomunikasi, tetapi teknologi juga memberikan banyak manfaat pada dunia pendidikan. Teknologi yang digunakan dalam pembelajaran dapat bermanfaat untuk membantu dalam visualisasi materi, dan membantu memotivasi belajar siswa. Keterampilan seperti kemampuan berkomunikasi, berfikir kreatif, berkolaborasi, berfikir kritis, pemecahan masalah dengan didukung penguasaan teknologi merupakan kompetensi yang harus dikuasai di abad 21 (Sutrisno, 2012; Sulman, 2012).

Penggunaan teknologi di sekolah terutama dalam pembelajaran fisika masih belum optimal, hal ini diebabkan oleh pemahaman guru yang kurang baik dalam menggunakan teknologi pada proses pembelajaran. Permasalahan ini terjadi pada proses mengkombinasikan antara strategi dan model pembelajaran dengan teknologi serta mengkalaborasikan antara materi pelajaran dan teknologi (Sastradika \& Jumadi, 2018). Pernyataan ini dibuktikan dengan penelitiannya yang dilaksanakan di SMAN 1 Kerinci, SMAN 4 Kota Jambi, SMAN 4 Kerinci (Sulman, 2012; Sastradika \& Jumadi, 2018).

Seiring dengan berkembangnya ilmu pengetahuan dan teknologi yang semakin pesat, dunia pendidikan juga mengalami perkembangan yang pesat pula. Fisika menjadi salah satu ilmu yang mengalami perkembangan. Namun fakta dilapangan menunjukkan bahwa proses pembelajaran Fisika di sekolah masih terdapat beberapa kekurangan. Salah satunya adalah prasarana yang dijadikan sumber belajar. Selain itu permasalahan yang sering terjadi dalam sistem pendidikan saat ini salah satunya adalah ketersediaan sumber belajar yang masih monoton. Beberapa sekolah biasanya mengandalkan buku paket atau LKS, dimana peserta didik malas untuk mempelajarinya. Hal ini dikarenakan buku paket yang relatif tebal, dan tampilan LKS yang kurang menarik minat belajar peserta didik.

Berdasarkan observasi awal di MAN 1 Kerinci pada tanggal 27 September 2019 diketahui bahwa terdapat $86 \%$ siswa kesulitan dalam mempelajari fisika. Siswa beralasan bahwa fisika merupakan mata pelajaran yang sulit untuk dipahami. Hasil selanjutnya yaitu sebesar $68 \%$ siswa menyatakan bahwa pembelajaran fisika pada materi suhu dan kalor memerlukan sumber belajar yang lebih inovatif agar materi mudah untuk dipahami dan dimengerti.

Hasil observasi melalui angket siswa didukung dengan hasil wawancara bersama guru. Dari hasil wawancara bersama guru diketahui bahwa proses pembelajaran Fisika di MAN 1 Kerinci masih menggunakan sumber belajar yang monoton dan kurang menarik, seperti hanya menggunakan buku paket dan LKS yang disediakan oleh pemerintah. Guru juga mengakui bahwa sumber belajar yang tersedia kurang inspritatif, inovatif dan kreatif, sehingga pembelajaran terkesan masih monoton dengan pendekatan tradisonal dan konvensional (Wawancara Guru Fisika). Kemampuan guru dalam menggunakan teknologi menjadi faktor utama terjadinya permasalahan ini. Kondisi tersebut menyebabkan pembelajaran Fisika menjadi kurang menarik, dan menjadi faktor utama rendahnya minat belajar siswa. Salah satu solusi untuk mengatasi masalah di atas adalah dengan mengembangkan E-LKPD berbasis Technological Pedagogical Content Knowledge (TPACK).

TPACK merupakan sebuah kerangka kerja dalam mendesain model pembelajaran baru dengan menggabungkan tiga aspek utama yaitu teknologi, pedagogi, dan konten (materi pengetahuan). Selain penggunaan teknologi sebagai bahan ajar belajar, dalam framework TPACK, pedagogi adalah aspek penting yang juga perlu diperhatikan dalam kegiatan pembelajaran. Pedagogi bukan saja bagaimana mengembangkan seni-seni dalam mengajar, atau mendesain kelengkapan instrumen-instrumen proses dan penelitian dalam permbelajaran, namun dituntut juga memahami siswa secara psikologis dan biologis. Dalam pemikiran secara pedagogis ini akhirnya ada sebuah penekanan, bahwa guru yang berhasil bukanlah guru yang hanya bisa menjadikan siswanya pintar, namun lebih dari itu yakni berhasil membantu siswa dalam menemukan dirinya sendiri. Minat, bakat serta karakter peserta didik akhirnya harus dipahami oleh seorang guru. 
Dengan mengembangkan E-LKPD berbasis Technological Pedagogical Content Knowledge (TPACK) diharapkan siswa mampu memahami konsep materi, menunjukan pengetahuan yang telah dimiliki, dan pembelajaran Fisika menjadi lebih menarik (Boisandi \& Anita, 2017). Tujuan penelitian ini adalah untuk mengembangakan sebuah sumber belajar elektronik berupa E-LKPD berbasis TPACK yang valid dan mampu membantu pembelajaran Fisika siswa kelas X.

\section{METODOLOGI}

Penelitian ini merupakan penelitian pengembangan dengan menggunakan model ADDIE (Analysis, Design, Develop, Implement, and Evaluate). Model ini dikembangkan oleh Branch (2009). Model ini terdiri 5 tahapan yang tersstruktur dan sistematis sehingga sangat tepat digunakan sebagai model pengembangan sumber ajar. Adapun langkah penelitian pengembangan ADDIE dalam penelitian ini jika disajikan dalam bentuk bagan pada gambar 1 (Sugiono,2017).

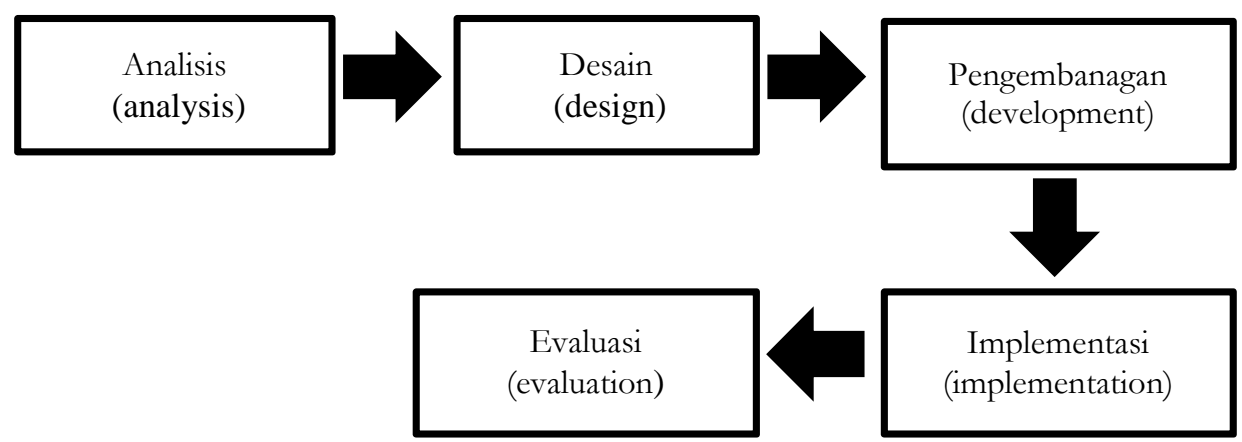

Gambar 1 Langkah Model Pengmbangan ADDIE

Data yang dikumpulkn selama proses pengembangan yaitu data kuantitatif dan data kualitatif. Data kuantitatif berupa hasil penilaian ahli terhadap produk yang dikembangakan. Sedangkan data kualittatif berupa masukan dan saran yang diberikan ahli serta temuan berupa dokumen pendukung dalam penelitian. Instrumen yang digunakan dalam pengumpulan data yaitu angket validasi bersama ahli media dan ahli materi. Hasil dari pengisian angket dianalisis dengan menggunakan rumus persentase berikut.

$$
\mathrm{P}=\frac{\sum k}{N} \times 100 \%
$$

Dimana:

$\mathrm{P} \quad$ : Presentasi skor

$\sum \mathrm{R}$ : jumlah keseluruhan skor jawaban yang diberikan tiap responden

$\mathrm{N}$ : jumlah keseluruhan skor ideal dalm satu item

Selanjutnya hasil tercapaian validasi disesuaikan dengan kategori penilaian pada Tabel 1 . (Arikunto, 2013; Sugiono, 2017).

Tabel 1 Kategori Penilaian Skala Likert

\begin{tabular}{cc}
\hline Rentang Skor $(\mathbf{P})$ & Kualifikasi \\
\hline $81 \%<\mathrm{P} \leq 100 \%$ & Sangat layak/sangat baik \\
\hline $61 \%<\mathrm{P} \leq 80 \%$ & Layak/baik \\
\hline $41 \%<\mathrm{P} \leq 60 \%$ & Kurang layak $/$ kurang \\
\hline
\end{tabular}




\section{TEMUAN}

Hasil pengembangan dari penelitian ini adalah berupa sebuah Lembar Kerja Peserta Didik Elektronik (E-LKPD) berbsais Technological Pedagogical Content Knowledge (TPACK) dengan materi Suhu dan Kalor. Produk ini dikembangkan menggunakan model ADDIE yang dilengkapi dengan uji validitas dan praktikalitas. Penilaian desain dan materi pembelajaran pada pengembangan ELKPD ini dilakukan oleh ahli desain dan ahli materi. Penilaian seluruh responden yang terdiri dari ujicoba kelompok kecil serta respons guru terhadap E-LKPD yang telah dibuat dengan menyebarkan angket.

Model pengembangan ADDIE yang terdiri dari lima tahapan yaitu tahap analisa (Analyze), desain (Design), pengembangan (Develop), implementasi (Implementation), dan penilaian (Evaluate). Model pengembangan ini memiliki keunggulan diantaranya yaitu dilihat dari prosedur kerjanya yang sistematik yakni pada setiap langkah yang akan dilalui selalu mengacu pada langkah sebelumnya yang sudah diperbaiki sehingga diharapkan dapat diperoleh produk yang efektif (Setiawan, 2017). Tahapan yang dilakukan pada pengembangan E-LKPD ini yaitu Analisis (Analyze), Desain (Design), dan Pengembangan (Develop). Produk yang dikembangkan adalah berupa Lembar Kerja Peserta Didik Elektronik (E-LKPD). Lembar kerja ini merupakan sebuah media pembelajaran yang memudahkan peserta didik dalam kegiatan penyelidikan atau pemecahan masalah. Pada LKPD ini terdapat panduan untuk latihan, uraian materi, tugas, dan latihan (Huda, Sulisworo, \& Toifur, 2017) Lembar Kerja ini didesain berbasis Technological Pedagogical Content Knowledge (TPACK).

\section{Technology Knowledge}

Technology Knowledge (TK) merupakan dasar-dasar teknologi yang dapat dimanfaatkan untuk mensupport pembelajaran. Contohnya pemanfaatan software, program animasi, internet akses, model molekul, laboratorium virtual dan lain-lain. Adapun teknologi yang digunakan dalam pengembangan e-LKPD ini adalah software 3D PageFlip. Aplikasi ini merubah tampilan file pdf/word/PowerPoint/excel ke bentuk flipbooks. Penggunaan aplikasi ini menjadikan media yang dikembangkan menjadi lebih menarik, interaktif dan kreatif. Bentuk E-LKPD yang ditampilkan menggunaakn flipbooks dapat dilihat pada Gambar 2.

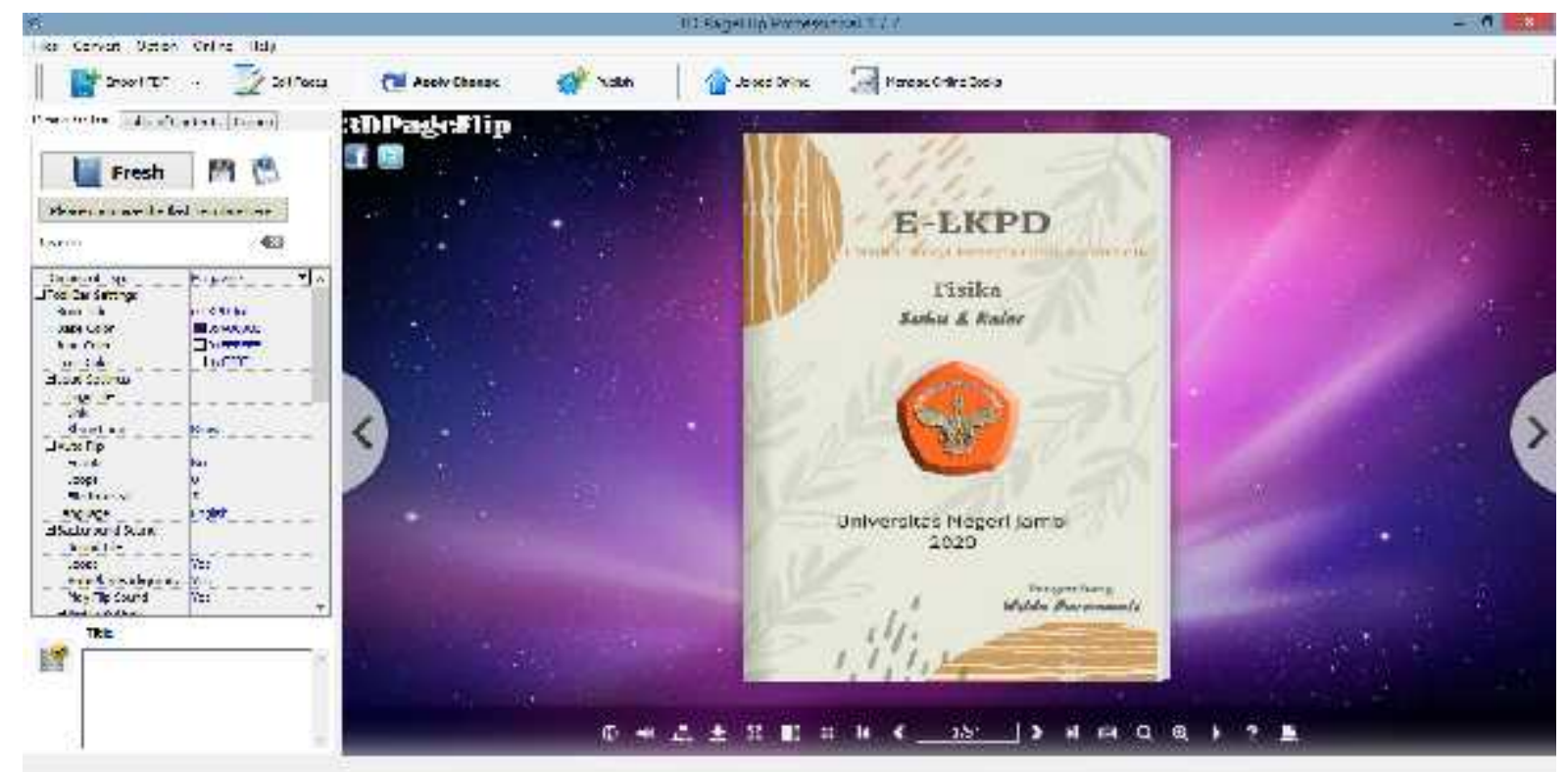

Gambar 2 Tampilan e-LKPD menggunakan 3D PageFlip

Selain itu, pengembangan e-LKPD ini juga diigtegrasikan penggunaan YouTube (contoh soal) dan Google Form (latihan soal \& tugas). Masing-masing tersaji pada Gambar 3 dan Gambar 4. 


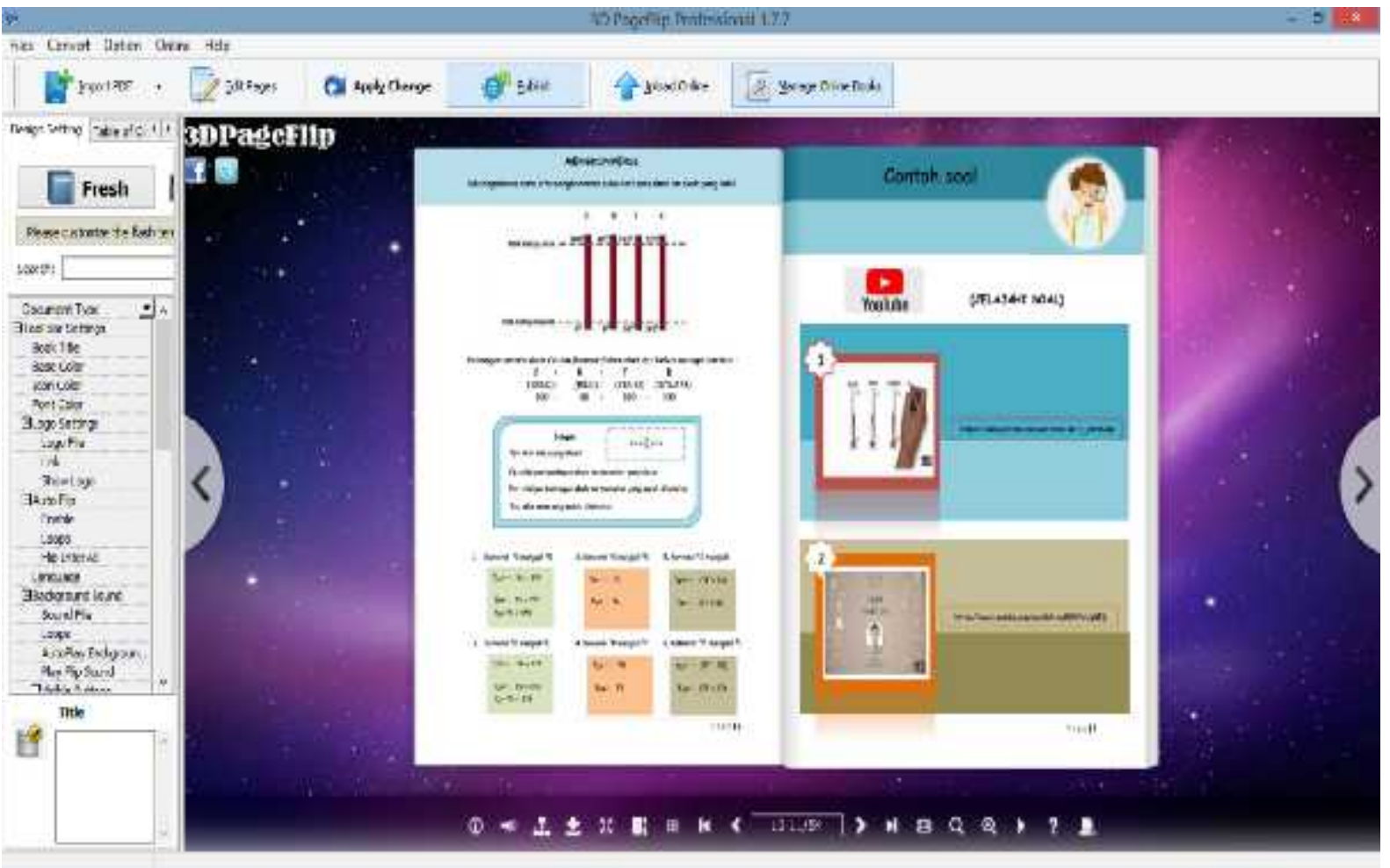

Gambar 3 Tampilan e-LKPD diintegrasikan ke Youtube

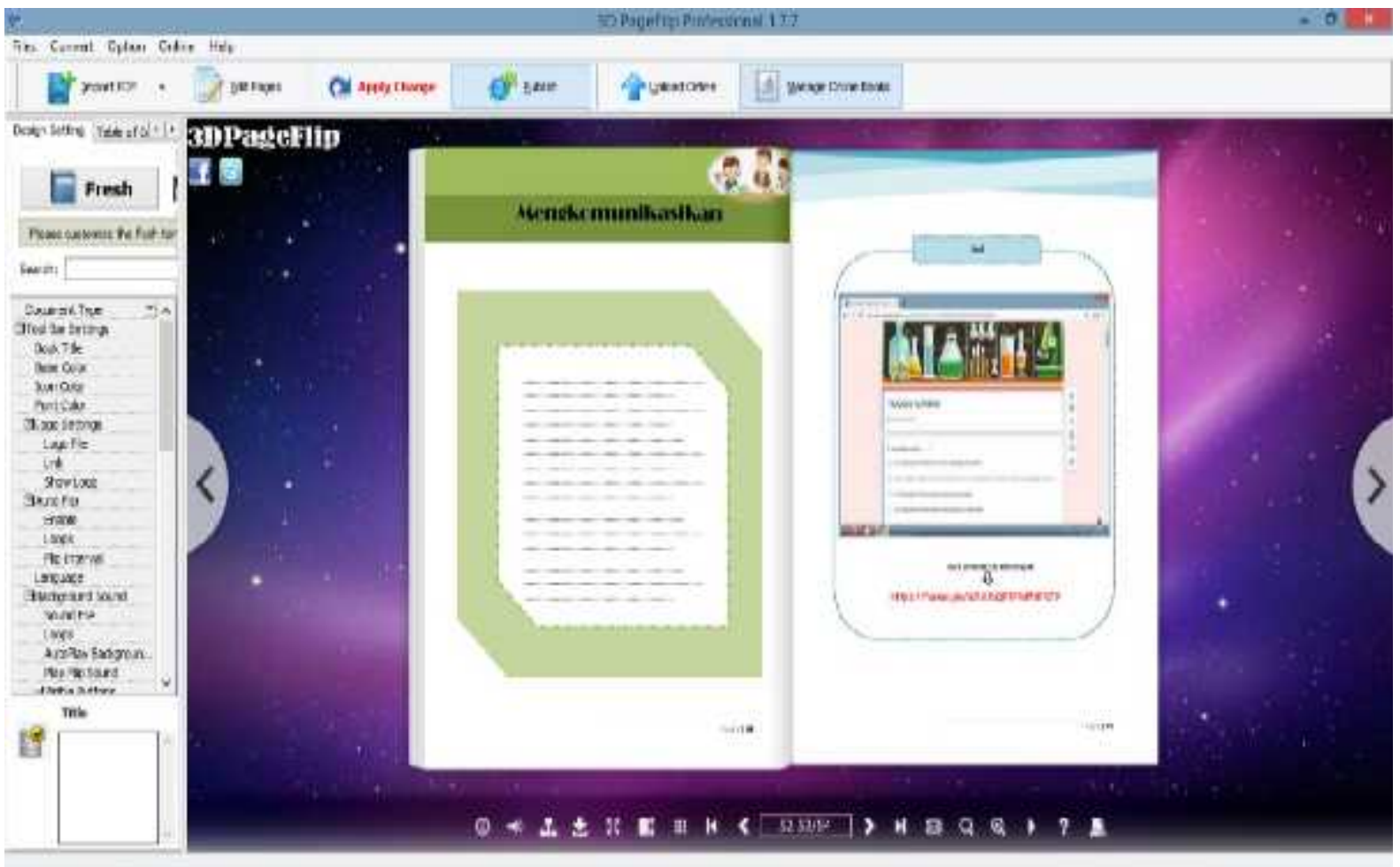

Gambar 4 Tampilan e-LKPD diintegrasikan ke Google Form

\section{Pedagogy Knowledge}

Pedagogy Knowledge (PK) yakni pengetahuan proses dan pelaksanaan atau metode pembelajaran yang digunakan. Dalam pengembangan e-LKPD ini menggunakan pendekatan 
saintifik 5M yaitu mengamati, menanya, mengumpulkan data, mengasosiasikan, mengkomunikasikan.

\section{Content Knowledge}

Content Knowledge (CK) yakni pengetahuan tentang materi pelajaran yang akan dipelajari. Adapun materi yang dibahas dalam pengembangan e-LKPD ini adalah materi Suhu dan Kalor.

\section{Techonology Pedagogy Knowledge}

Techonology Pedagogy Knowledge (TPK) adalah serangkaian pemahaman bagaimana perubahan pembelajaran terjadi dengan memanfaatkan teknologi yang digunakan untuk mendukung pembelajaran secara aktif. Pengembangan e-LKPD ini Menggunakan 3D Flip page ebook dengan pendekatan saintifik $5 \mathrm{M}$.

\section{Technology Content Knowledge}

Technology Content Knowledge (TCK) yakni pengetahuan tentang cara teknolofi menciptakan representasi baru dari suatu materi sedemikian sehingga merubah cara peserta didik dalam memahami suatu konsep dari materi pelajaran melalui penggunaan teknologi. Menggunakan 3D PageFlip ebook untuk memahami Suhu dan Kalor.

\section{Pedagogical Content Knowledge}

Pedagogical Content Knowledge (PCK) yakni pengetahuan terhadap cara memadukan antara materi pembelajaan dengan pedagogik untuk mengembangkan proses pembelajaran yang lebih baik (Misha \& Koehler, 2006). Adapun langkah-langkah pembelajaran dengan pendekatan Saintifik 5M adalah observing (mengamati), questioning (menanya), mengumpulkan informasi/eksperimen, mengasosiasikan/mengolah informasi, mengkomnikasikan. Dengan mengoptimalkan kemampuan berpikir ilmiah, peserta didik dapat menyelesaikan berbagai kesulitan dalam pembelajaran materi suhu dan kalor.

Setelah produk awal dikembangkan maka dilanjutkan dengan validasi bersama ahli media dan ahli materi. Berdasarkan hasil validasi diketahui bahwa E-LKPD yang dikembangan sudah memiliki nilai yang sangat baik. Hasil validasi dapat dilihat pada Tabel 2.

Tabel 2 Validitas Ahli Materi dan Ahli Media

\begin{tabular}{|c|c|c|}
\hline Validator & Indeks Validitas & Kategori \\
\hline Ahli Media & $96,42 \%$ & Sangat Layak \\
\hline Ahli Materi & $100 \%$ & Sangat Layak \\
\hline
\end{tabular}

Pada Tabel 2, dijabarkan tentang penilaian ahli media dan ahli materi. Pada penilaian ahli media, indikator yang digunakan berupa variasi warna, bahasa, grafis dan desain produk yang dikembangkan. Pada validasi materi, indikator penilaian yang digunakan yaitu kesesuaian media dengan pembelajaran, kesesuaian media dengan kurikulum, isi materi dan interaksi atau umpan balik.

\section{DISKUSI}

Penilaian kesesuaian media dengan pembelajaran yaitu penilaian media yang didasarkan pada kemenarikan media yang dikembangkan terhadap kelompok belajar, kemenarikan judul dan relevansi materi berdasarkan hasil penilaian ahli diketahui bahwa materi yang dikembangkan pada aspek pembelajaran mendapatkan penilaian dengan kategori sangat baik.

Penilaian materi yang disesuai kurikulum diketahui bahwa media telah disusun berdasarkan kurikulum yang berlaku di sekolah sehingga mendapatkan nilai yang baik dari ahli materi. Penilaian 
selanjutnya pada validasi materi yaitu aspek isi materi dan interaksi umpan balik. Dari hasil penilaian ahli didapatkan hasil bahwa isi materi telah disesuaikan dengan kebutuhan peserta didik yang didasarkan pada cakupan Kompetensi Inti dan Kompetensi Dasar. Media yang dikembangkan juga mudah dioperasikan dan menarik. Hal ini menyebabkan media mendapatkan nilai yang sangat baik pada aspek penilaiain interaksi dan umpan balik.

Berdasarkan penjabaran pada paragraf sebelumnya mengenai hasil validasi materi maka dapat dinyatakan bahwa media telah memiliki materi yang sangat baik. Hal ini dibuktikan dengan penilaian validator materi dengan rerata persentase jumlah skor akhir yaitu sebesar $100 \%$ dengan kategori sangat baik. Nilai akhir yang dapat dikatakan sempurna ini didapatkan dari hasil revisi yang dilakukan setelah pengecekan oleh validator. Pada proses validasi terdapat tiga kali perbaikan yang dilakukan hingga dapat hasil yang layak. Menurut Charlina \& Septyanti (2019) produk yang divalidasi memerlukan perbaikan hingga produk yang dikembangkan dikatakan layak digunakan pada tahap selanjutnya. Hasil validasi memberikan pengaruh signifikan dalam perbaikan produk yang dikembangkan (Cahyaningrum, Nurjayadi, \& Rahman, 2017; Setiawan, dkk., 2020). Pembuatan susunan media e-LKPD memperhatikan prinsip umum teori pembelajaran Behaviorisme, teori belajar Kontruktivisme dan teori kognitivisme.

Prinsip utama teori Behaviorisme yaitu meletakkan karakteristik peserta didik dan lingkungan belajar sebagai dasar utama guru dalam menentukan rancangan dan pola pembelajan (Riyanto, 2009). Kemudian, proses design yang didasarkan atas prinsip utama teori belajar Kontruktivisme yaitu guru merancang pembelajaran dengan sebaiknya sehingga peserta didik dapat membangun pengetahuannya secara pribadi. Proses akhir desain juga memperhatikan hasil belajar yang akan didapat peserta didik. Hasil belajar dapat berupa perubahan konsep pemikiran, persepsi terhadap materi dan perubahan tingkah laku menjadi lebih baik. Dari pertimbangan konsep teori belajar tersebut, diharapkan E-LKPD yang dikembangkan mampu menjadi sumber belajar peserta didik.

Selanjutnya berdasarkan hasil validasi diketahui bahwa produk telah memiliki kombinasi warna yang sangat baik dan warna yang diberikan tidak mengganggu materi. Selanjutnya kalimat yang disusun pada media mudah dibaca dan meunggunakan huruf yang jelas. Hal ini menyebabkan teks atau bahasa tulisan pada media mudah dimahami dan dinilai sangat baik.

Pada bagian grafis dan desian, ahli menyatakan bahwa media ini memiliki nilai yang baik. Dari hasil penilaian ini ahli dapat dilihat bahwa nilai akhir dari validator ahli media yaitu 96,24\% dengam kategori sangat layak. Berdasarkan nilai ini dapat disimpulkan media yang dikembangkan sangat baik dan dapat digunakan pada tahap selanjutnya. Selanjutnya menurut hasil riset yang dilakukan oleh Cahyaningrum, Nurjayadi, \& Rahman (2017) bahwa media yang memiliki validitas sangat baik dan layak digunakan menjadi sumber belajar.

\section{SIMPULAN}

Penelitian ini menggunakan model pengembangan ADDIE yang terdiri dari 5 tahap yaitu analisis (Analysis), desain pengembangan (Design), pelaksanaan pengembangan (Development), implementasi (Implemntation), evaluasi (Evaluation). Pada akhirnya menghasilkan produk yakni lembar kerja peserta didik elektronik (E-LKPD) berbasis Technological Pedagogical Content Knowledge (TPACK) pada mata pelajaran Fisika Siswa kelas X. Media pembelajaran E-LKPD yang dihasilkan dikategorikan sangat layak untuk digunakan dalam pembelajaran Fisika kelas X materi Suhu dan Kalor.

\section{REFERENSI}

Arikunto, S (2013). Prosedur Penelitian: Suatu Pendekatan Pratik. Jakarta: Rineka cipta 
Boisandi \& Anita (2017). Pengembangan modul eksperimen fisika material sollar cell berbasis TPACK. Jurnal Edukasi, 15(1).

Branch, R. M. 2009. Instructional Design: ADDIE. London: Springer.

Cahyaningrum, R. D., Nurjayadi, M., Rahman, A. (2017). JRPK: Jurnal Riset Pendidikan Kimia, 7(1), 59-65.

Charlina \& Septyanti, E. (2019). Development of Work Sheets for Student (LKPD) in Writing Explanation Text. ELS Journal on Interdisciplinary Studies on Humanities, 2(4), 515-528.

Huda, Sulisworo, \& Toifur (2017). Analisis buku ajar termodinamika dengan konsep technologikal pedagogical and content knowledge (TPACK) untuk penguatan kompetensi belajar mahasiswa. Jurnal Penelitian Pembelajaran Fisika, 8(1). Available Online at http://journal.upgris.ac.id/index.php/JP2F

Riyanto, Y. (2009). Paradigma Baru Pembelajaran. Jakarta: Kencana Prenada Media Grup.

Sastradika, D., \& Jumadi. (2018). Development of subject-specific pedagogy based on guided inquiry about newton' s law to improve senior high school students' scientific literacy ability Development of subject-specific pedagogy based on guided inquiry about newton' $\mathrm{s}$ law to improve sen. In Journal of Physics: Conference Series (pp. 1742-6596). IOP Publishing. https://doi.org/10.1088/1742-6596/1097/1/012017.

Setiawan, M. E. (2017). Pengembangan Buku Ilmiah Populer Untuk Masyarakat Pencinta Alam Melalui Ekplorasi Tumbuban Survival di Taman Nasional Bromo Tengger Semeru. (Thesis: Universitas Negeri Malang).

Setiawan, M. E., Musdizal, M., Suhadi, S., Sastria, E., Haryanto, T., Novinovrita M, N. M., Angela, L., Lardiman, H., Ahmad, B., \& Habibi, M. (2020). The Practicality and Validity of the opular Scientific Book Development 'Survival Plants'. International Journal of Scientific \& Technology Research, 9(2), 9970-5000.

Sugiono. (2017). Metode Penelitian Kuantitatif, Kualitatif, dan R\&DD. Bandung: Alfabeta.

Sulman, F. (2012). Pengarub Penggunaan Model Pembelajaran Kooperatif Tipe Problem Posing Dan Motivasi Awal Terhadap Hasil Belajar Fisika Siswa SMAN 12 Padang. Universitas Negeri Padang.

Sutrisno. (2012). Pengantar Pembelajaran Inovatif Berbasis Teknologi Informasi \& Komunikasi. Jakarta: Gaung Persada. 